\title{
KONFLIK AGRARIA ANTARA PEMERINTAH DENGAN MASYARAKAT DUSUN BONDU DESA ARABIKA KABUPATEN SINJAI
}

\author{
Muhammad Nur ${ }^{1 *}$, Idham Irwansyah ${ }^{2}$ \\ ${ }^{1}$ Mahasiswa Jurusan Sosiologi Fakultas Ilmu Sosial \\ Universitas Negeri Makassar \\ Email: Muhammadnurve@gmail.com \\ ${ }^{2}$ Dosen Sosiologi/ Universitas Negeri Makkassar \\ Email:idham.irwansyah@unm.ac.id
}

\begin{abstract}
ABSTRAK
Bertujuan untuk mengetahui faktor faktor yang melatar belakangi konflik agraria antara Pemerintah dengan Masyarakat di Dusun Bondu Desa Arabika dan upaya pemerintah dalam penyelesaian Konflik Agraria di Dusun Bondu Desa Arabika. Hasil penelitian ini .menunjukkan bahwa konflik agraria yang terjadi antara pemerintah dengan masyarakat di Dusun Bondu Desa Arabika Kecamatan Sinjai Barat Kabupaten Sinjai di latar belakangi oleh beberapa faktor yaitu faktor kepemilikan tanah,faktor ekonomi,faktor hokum, faktor sosialisasi,faktor pendidikan,faktor tindakan koersif,faktor kebijakan. Adapun upaya yang di lakukan pemerintah untuk menyelesaikan konflik agraria yaitu Konsiliasi dengan memepertemukan kedua belah pihak yang berkonflik untuk mencapai tujuan bersama, Mediasi pemberhentian kedua belah pihak yang berkonflik tetapi tidak diberikan keputusan yang mengikat dan Arbitrasi suatu keputusan yang diambil dengan di keluarkanya surat keputusan yang harus di taati oleh kedua pihak yang berkonflik.
\end{abstract}

Kata kunci : Konflik, Agraria, Pemerintah dan masyarakat

\begin{abstract}
It aims to determine the factors behind the agrarian conflict between the Government and the Community in Bondu Hamlet, Arabica Village and the government's efforts to resolve Agrarian Conflict in Bondu Hamlet, Arabica Village. The results of this study indicate that the agrarian conflict that occurs between the government and the community in Bondu Hamlet, Arabika Village, West Sinjai District, Sinjai Regency is motivated by several factors, namely land ownership, economic factors, legal factors, socialization factors, educational factors, coercive action factors., policy factor. As for the efforts made by the government to resolve agrarian conflicts, namely conciliation by bringing together the two parties in conflict to achieve common goals, Mediation of dismissal of both parties in conflict but not given a binding decision and Arbitration of a
\end{abstract}


decision taken by issuing a decision letter that must be issued. be obeyed by both parties to the conflict.

Keywords: Conflict, Agrarian, Government and society

\section{PENDAHULUAN}

Konflik Agraria adalah pertentangan klaim mengenai satu bidang tanah, wilayah, dan sumber daya alam antara masyarakat petani dengan pemerintah. Konflik ini berawal adanya kebijakan yang dibuat oleh pemerintah yang merugikan masyarakat sehingga memicu hadirnya konflik. Struktur kepemilikan tanah di Indonesia terkadang sangat timpang, seperti masalah hak dan akses masyarakat di dusun Bondu. Hak dan akses masyarakat terhadap tanah kadang tidak diakui oleh pemerintah memicu hadirnya konflik, seperti konflik agraria antara pemerintah dengan masyarakat di dusun Bondu desa Arabika kecamatan Sinjai Barat kabupaten Sinjai.

Kepala Dinas Kehutanan Sulsel Syukri Mattinetta mengungkapkan bahwa dari 21,1 juta Hektare hutan yang dimiliki Sulawesi Selatan, seluas 20.000 Hektare berpotensi konflik sebab persoalan batas tanah milik masyarakat dengan kawasan hutan lindung diantaranya di Kab. Sinjai, Bulukumba, Bone, Luwu Utara dan Kab. Luwu. Tanah yang masih bersengketa dijadikan hutan kemasyarakatan dan tidak boleh ada sertifikat maupun jual beli lahan. Seperti halnya di dusun Bondu desa Arabika kabupaten Sinjai merupakan persoalan hak milik tanah antara milik petani dengan milik Dinas Kehutanan yang dijadikan kawasan hutan lindung, yang ingin dialih fungsikan sebagai kawasan hutan masyarakat.

Adanya keputusan yang sepihak diambil oleh pemerintah ini mengindikasikan bahwa pengambilan kebijakan tidak melibatkan masyarakat dalam hal ini penetapan kawasan hutan lindung yang berdampak negatif pada masyarakat, dimana tanah mereka dimasukkan dalam kawasan hutan lindung sementara masyarakat tidak tahu hal itu. Konflik kepentingan ini mulai muncul di permukaan saat polisi kehutanan melakukan pengrusakan tanaman pohon cengkeh masyarakat yang selaus 50 Ha yang di kelola oleh masyarakat Bondu desa Arabika sebagai tanah warisan yang di tanami pohon cengkeh untuk keberlangsungan hidup masyarakat Bondu.

Konflik antara masyarakat di dusun Bondu dan pihak polisi kehutanan terjadi pada bulan November-Desember tahun 2013 dimana polisi kehutanan langsung menebang tanaman masyarakat tanpa sosialisasi. Konflik belum selesai dilihat belum adanya kepemilikan hak tanah. Terlihat adanya demostrasi pada hari Rabu 26 November 2014 sejumlah mahasiwa dan warga melakukan aksi unjuk rasa depan kantor dinas kehutanan dan polres Sinjai mendesak agar tanah warga yang masuk kawasan hutan lindung untuk di kembalikan dan meminta kepada polisi agar tidak mengitimidasi warga.

\section{METODE}

Penelitian ini menggunakan metode penelitian kualitatif. Dengan informan penelitian berjumlah 11 orang. Di peroleh dengan menggunakan teknik purposive sampling dengan kriteria masyarkat yang terlibat konflik yang berumur 27-56 tahun, Pemerintah dalam hal ini Kepala Desa dan Lurah,dan dinas Kehutanan. Teknik pengumpulan data dilakukan melalui observasi, wawancara, dan dokumentasi dengan tahap teknik analisis data kualiatatif yang bersifat deskriptif yaitu mengumpulkan data, reduksi data, menyajikan data, dan menarik kesimpulan. 


\section{HASIL DAN PEMBAHASAN}

\section{a. Faktor Faktor Penyebab Terjadinya Konflik Agraria}

Dengan adanya perbedaan kepentingan antara pemerintah dengan masyarakat menyangkut persoalan tanah dapat membangkitkan pertikaian (konflik). Kelompokkelompok kepentingan yang berbeda dalam system sosial akan saling mengejar tujuan yang berbeda.Seperti hal penelitian ini adanya kepentingan yang berbeda antara pemerintah dengan masyarakat,dimana pemerintah mengklaim bahwa tanah itu sebagai kawasan hutan lindung dan sehingga mengarahkan mereka untuk melakukan tindakan pengrusakan tanaman masyarakat sementara masyarakat menganggap tanah yang di kelolahnya sebagai tanah warisan. Hal ini sesuai dengan pandangan Lock Wood, bahwa kekuatan-kekuatan yang saling berlomba dalam mengejar kepentingannya akan melahirkan mekanisme ketidakteraturan sosial (socialdisorder). Pemerintah dengan masyarakat Bondu Kecamatan Sinjai Barat Kabupaten Sinjai. Adanya kekuatan dari pihak pemerintah yang mengatas namakan hukum dan sebuah kebijakan yang di ambil pemerintah sehingga melakukan sebuah tindakan untuk kepentinganya, sementara dari pihak masyarakat yang memahami bahwa itu adalah sebuah tanah warisan dan persoalan ekonomi sehingga tidak ada solusi lain selain mempertahankannya.

Adanya perbedaan kepentingan ini seperti dalam teorinya Dahrendorf yang membedakan golongan yang terlibat konflik itu menjadi dua tipe. Kelompok semu (quasi group) merupakan kumpulan dari para pemegang kekuasaan atau jabatan dengan kepentingan yang sama yang terbentuk karena munculnya kelompok kepentingan. Tipe yang kedua adalah kelompok kepentingan (interest group), terbentuk dari kelompok semu yang lebih luas.Kelompok kepentingan ini mempunyai struktur, organisasi, program, tujuan serta anggota yang jelas. Kelompok kepentingan inilah yang menjadi sumber nyata timbulnya konflik dalam masyarakat.

Pada konflik pemerintah dan masyarakat di Dusun Bondu, terjadi harapan peran yang disadari (kepentingan tersembunyi telah disadari).Kelompok kepentingan ini telah memiliki struktur organisasi dan tujuan yang jelas yang di perankan oleh pihak pemerintah. Masyarakat Bondu menyadari kepentingan yang ia perjuangkan yakni mempertahankan tanahnya sebagai sumber penghidupanya.

Kekuasaan menjadi penyebab timbulnya perlawanan. Esensi kekuasaan yang dimaksud oleh Dahrendorf adalah kekuasaan kontrol dan sanksi sehingga memungkinkan mereka yang memiliki kekuasaan memberi berbagai perintah dan mendapatkan apa yang mereka inginkan dari mereka yang tidak memiliki kekuasaan.seperti halnya Polhut atas perintah dinas kehutanan melakukan tindakan anarkis untuk mendapatkan yang mereka inginkan Jadi, konfik kepentingan menjadi fakta tidak terhindarkan dari mereka yang memiliki kekuasaan dan tidak memiliki kekuasaan.

Perbedaan kepentingan mengenai kehidupan yang mendasar dalam hal ini persolan tanah menjadikan perseturuan karena sebuah kebijakan yang merugikan salah satu pihak. Pandangan Lewis A. Coser (Marga M. Poloma, 1992:103) mengakui beberapa susunan struktural merupakan hasil persetujuan dan konsensus, yang menunjukkan pada proses lain yaitu konflik sosial. Dalam berbagai situasi konflik, Coser membahan konflik yang realistis. Konflik yang realitis berasal dari kekecewaan terhadap tuntutan-tuntutan khusus/tertentu yang terjadi dalam hubungan kedua belah pihak.

Kenyataan ini terlihat pada pandangan toeri konfliknya berikut ini. Menurut Dahrendorf (Margaret M. Poloma, 1992: 137) pertentangan kelas harus dilihat sebagai kelompok-kelompok pertentangan yang berasal dari struktur kekuasaan asosiasi-asosiasi yang terkoordinir secara pasti. Kelompok-kelompok yang bertentangan itu sekali mereka 
ditetapkan sebagai kelompok kepentingan, akan terlibat dalam pertentangan yang niscaya akan menimbulkan perubahan struktur sosial.

Kekuasaan atau otoritas mengandung dua unsur yaitu penguasa (orang yang berkuasa) dan orang yang dikuasai atau dengan kata lain atasan dan bawahan. Kelompok dibedakan atas tiga tipe antara lain : 1. Kelompok Semu (quasi group) 2. Kelompok Kepentingan (manifes) 3. Kelompok Konflik Kelompok semu adalah sejumlah pemegang posisi dengan kepentingan yang sama tetapi belum menyadari keberadaannya, dan kelompok ini juga termasuk dalam tipe kelompok kedua, yakni kelompok kepentingan dan karena kepentingan inilah melahirkan kelompok ketiga yakni kelompok konflik sosial. Sehingga dalam kelompok akan terdapat dalam dua perkumpulan yakni kelompok yang berkuasa (atasan) dan kelompok yang dibawahi (bawahan).

\section{b. Upaya Penyelesaian Konflik}

Akar dari persoalan konflik dikawasan hutan lindung karena sebuah persoalan tidak adanya kepastian pengelolaan antara pemerintah dengan masyarakat. Tumpang tindih klaim atas kebijakan yang tidak terformulasi jelas yang berakibat penutupan akses masyarakat. Terjadinya konflik agraria dalam masyarakat jelas memiliki dampak terhadap kehidupan sosial masyarakat sebagai akibat dari adanya keguncangan sosial, oleh karenanya berbagai upaya penanganan konflik telah dilakukan agar kembali tercipta tatanan sosial yang lebih baik. Dengan mempertemukan kepentingan pihak yang berkonflik untuk menyelesaikan perselisihan ini dilakukan Kantor kepala desa Arabika.

Sejalan yang diungkapkan Nasikun dalam (Zaenal, 2002:26). Konsiliasi merupakan bentuk pengendalian konflik sosial yang di lakukan oleh lembaga-lembaga tertentu yang dapat memberikan keputusan dengan adil. Seperti halnya di lakukan oleh pemerintah sinjai dengan di keluarkannya peraturan terkait sengketa tanah dengan memberikan keleluasaan kepada masyarakat Bondu tetap mengolah lahan mereka.

\section{SIMPULAN}

Berdasarkan penelitian mengenai konflik agraria antara pemerintah dengan masyarakat di dusun Bondu desa Arabika kec.Sinjai barat Kab. Sinjai. Mengenai faktor faktor yang melatar belakangi konflik agraria yaitu mengenai kepemilikan tanah, dimana tanah yang dikelolah oleh masyrakat di klaim sebagai kawasan hutan lindung, faktor ekonomi menjadi menjadi alasan masyarakat tetap mempertahankan tanahnya karena tidak adanya penghidupan atau pekerjaan lain, rendahnya pendidikan warga bondu sehingga ketidaktahuan hukum apalagi dalam pengurusan sertifikat tanah, fkctor kebijakan yang di keluarkan oleh pemerintah mengarahkan Polhut melakukan tindakan refresif,sebuah tindakan menurut pemerintah itu keharusan untuk menjaga kestabilan dan atas landasan hokum mereka melakukan pencabutan tanaman masyarakat, Tidak adanya sosialisasi terhadap masyarakat sehinggam memicu konflik terbuka antara pemerintah dengan masyarakat Bondu desa Arabika Kecamatan Sinjai Barat Kabupaten Sinjai. Upaya yang di lakukan pemerintah dalam menyelesaikan konflik dengan cara mediasi,konsiliasi, dan arbitrasi sehingga dalam penyelesaianya di kelurkannya surat keputusan dari bupati sinjai mengenai pengelolaan lahan sebagai landasan hukum. 


\section{DAFTAR PUSTAKA}

A.Savitri, Laksmi, Valentin. A, Ahmad. N.L. Pengembangan Kebijkan Agraria untuk Keadilan Sosial, Kesejahteraan Masyarakat dan Keberlanjutan Ekologis. Yogyakarta: Sains. 2010.

Andi MulianiSultani. Konflik dan Kebijakan Agraria di Indonesia dari Masa ke Masa.tugas kebijakan pertanahanprogram studi ilmu perencanaan wilayahsekolah pascasarjana institut pertanian Bogor.7 November 2012.

Gunawan, Wiradi., Benyamin. W., William L. Coller,. Soentoro.. Makali., Chris M. Ranah Studi Agraria Penguasaan Tanah dan Hubungan Agraris. Yogyakarta: STPN Press. 2009

Ismaya,Samun. Pengatar hukum agrarian. Yogyakarta: Graha Ilmu. 2011.

Koentjaraningrat. Metode-Metode Penelitian Masyarakat. Jakarta: Gramedia. 1991. Cet. XI.

Marlang, Abdullah. Pengantar hukum indonesia, Makassar: As. Center, 2009.

Ranoemihardja, R. Antang. Perkembangan hukum agraria di indonesia,aspek- aspek dalam pelaksanaan UUPA dan peraturan undang undangan lainya dibidang agraria di indonesia, Bandung : Tarsito, 1982

Rokhiman, Muryanti, Dwi Nugroho Dawar. Teori konflik dan konflik agraria pedesaan, Bantul: Kreasi Wacana, 2013

Rousseau,jean jacques. Kontrak sosial atau prinsip hukum- politik, Jakarta: Dian Rakyat , 2010.

Salim, emil. Pembangunan berwasasan lingkungan, Jakarta :LP3ES, 1986.

Savitri, Laksmi Adriani, Mohammad Sohibuddin, \& Surya Saluang. Memahami \& Menemukan Jalan Keluar Dari Problem Agraria \& Krisis Ekologi. Yogyakarta: Sekolah Tinggi Pertanahan nasional. 2010.

Soetomo, S. H. Pembebasan, pencabutan, permohonan, hak atas tanah usaha nasional, Surabaya: 1984.

Sutiknyo, Iman. Politik agraria nasional, yogyakarta : Gadjah Mada University, 1990.

Sugiyono. Metode Penelitian, Kualitatif, dan R\&D. Bandung: Alfabeta. 2011.

Suharsaputra, Uhar. 2012. Metode Peneitian Kuantitatif, Kualitatif, dan Tindakan. Bandung; PT Refika Aditama

Susan, Novri. Pengantar sosiologi konflik dan isu-isu konflik kontemporer.Jakarta : Kencana. 2009.

Tjondronegoro, Sesiono.MP. \& Gunawan Wiradi (2004): "Menelusuri Pengertian Istilah Agraria”. Dalam Jurnal Analisis Sosial. Vol.9. No. 1, April 2004. Bandung.

Tjondronegoro, Soediono. Keeping-keping sosiologi dari pedesaan.Bogor : Direktorat Jenderal Pendidikan Tinggi. 1999.

Wiradi, Gunawan. Seluk Beluk Masalah Agrariareforma Agraria dan Peneltian Agraria. Yogyakarta: Sekolah Tinggi Pertanahan nasional.2009.

Undang-undang No. 5 tahun 1960 Tentang peraturan dasar pokok-pokok agraria.

Peraturan pemerintah republik indonesia Nomor 24 tahun 2010 tentang penggunaan kawasan hutan.

Peraturan presiden republik indonesia Nomor 28 tahun 2011Tentang penggunaan kawasan hutan lindung untuk penambangan bawah tanah. 
Peraturan menteri kehutanan republik indonesia Nomor : P.39/Menhut-II/ 2013 tentang pemberdayaan masyarakat setempat melalui mitra kehutanan.

Undang- undang republik indonesia Nomor 18 tahun 2013 tentang pencegahan dan pemberantasan dan perusakan hutan.

http://koranpembebasan.wordpress.com/2013/04/09/pernyatan-sikap-gerakan-rakyat-antiperampasan-tanah-dan-kekerasan/

http://makassar.tribunnews.com/search/?q=konflik+agraria+di+sinjai+barat+november+2 $013 \& \mathrm{cx}=$ partner-pub$\underline{7486139053367666 \% 3 \mathrm{~A} 7016215912 \& \mathrm{cof}=\mathrm{FORID} \% 3 \mathrm{~A} 10 \& \mathrm{ie}=\mathrm{UTF}-8}$

https://jurnaltoddoppuli.wordpress.com/category/budaya-2/page/44/

http://kabaramansulsel.wordpress.com/category/sinjai/

http://www.mongabai.co.id/tag/kriminalisasi -warga sinjai/

http://news.okezone.com/read/2012/03/07/340/588432/20-000-hektare-hutan-sulselrawan

http://www.makassartv.co.id/index.php?option=com content\&id=13341:batas-kawasanhutan-lindung-di-sinjai-ditinjau-ulang\&Itemid $=58$

http://makassar.tribunnews.com/2014/11/26/mahasiswa-desak-dinas-kehutanan-sinjaikembalikan-hutan-rakyat 